International Journal of Research in Engineering and Innovation
(IJREI)
journal home page: http://www.ijrei.com
ISSN (Online): 2456-6934

\title{
Lean applications in improving quality by minimizing wastes in higher education sector in Indian context- A review
}

\author{
Kamini Mishra
}

Delhi Technological University Delhi, India

\begin{abstract}
This paper described the importance of lean application in the work process of planning the course and delivery for improving total quality management in Indian universities/institutions. The effects of lean philosophy in the work process (present and future) studied in details. It was found that the impact of implementation of lean for determining the efficiency of staff, faculty using student's satisfaction reduced the costs in higher education sector. (C)2019 ijrei.com. All rights reserved
\end{abstract}

Keywords: Higher Education Sector, Minimizing Wastes, Total quality Management.

\section{Introduction}

Lean was introduced by Toyota in Japan and was known as Toyota Production System. Lean is a method to improve the production flow by minimizing the waste continuously in the process. Wastes are actions, or results from actions that doesn't contribute in increasing organization value. Lean can also be defined as few or minor, which means there would be lesser waste of the costs, time usage, layers of an organization and suppliers per customer, according to Nightingale [1] . Also [2] defined lean as, in the sense of empowerment of the employee's capability, flexibility, productivity, quality, customer satisfaction and longterm success in competition among organizations. The lean principles explained in the 3 levels: Lean philosophy, Lean principles, and Lean tools/techniques/methods. This paper likely to contribute to the literature by finding out any activity which is not valuable in the planning the course and delivery process in the higher education sector and helping with improving the work process by minimizing the wastages in higher education sector. The Logothetis [3] suggested the implementation of TQM concepts in education sector .TQM elements are indicators that clarifies the customer's need (students, parents and society). And important for education provider to determine and monitor the design of education and quality of course provided and suggested that education providers must use various tools for controlling the quality and improving continuously. Spanbauer
[4] reviewed education service with the application of TQM concepts i.e. leadership; education and training; customer service; organizational climate; meaningful data; scientific methods and tools; and team problem solving and observed that the serving the customer is number one priority of education sector and important in minimizing the wastes in education sector .Filling up the expectation customers is new concept emerged in education sector as educators are persons who knows what is best for the students. Dahlgaard, et.al. [5] analyzed the philosophy of total quality management (TQM) in education. Principles of TQM and ways to implement them in the education were highlighted in paper i.e. leadership; customer and employee focus; kaizen (continuous improvement); the participation of everybody; and focusing on facts. The paper also introduced plan do check act (or PDCA) model in applying quality in leadership in the education service sector. This paper is said to have contributed to the application of the Lean principle in education as kaizen, customer and employee focus, and focusing on facts have strong links with the Lean principle. As a matter of fact, providing academic service in higher education can be a meticulous business [6] because the higher education service is a sector that needs to be continuously changed and improved to cope with the academia and the today's era of knowledge. Domonio theory [7], every higher education organisation has started to build their uniqueness so that they can be more easily 
differentiated than others. This shows the fruitfulness of academic program developer roles and usually also indicates the educational programs provided by those organizations can be challenging, thrilling or frustrating. Collins and Muthusamy [8] Lean principle facilitates health service to remove mistakes and reduction of delays, waiting times and to respond the procedures in health service. Womack and Jones [9, 10] examined the application of Lean principle in hospital management. This can be initiated in the process of assigning patients during their reception, managing their medical attention waiting times, assuring their comfort during their stay and measuring the quality of the services that have been provided to them by the hospital. Martin [11] found approximately of $19 \%$ health service organizations in the USA adopted Lean principles such as six sigma lean thinking- $13 \%$,outsourced health service-12\%, No application of Lean principle -29\%.Justification of low adoption of Lean principle in the health service sector and more efforts should be made to improve health service. Levit [12] used lean principles in manufacturing sector like plan, control, and assurance of quality, kaizen and handling of customer responses results in higher customer satisfaction. Usage of proper technology and standardization. Skinner [13] claimed that the service sector is being led by the manufacturing sector in the sense of looking for ways and mechanisms to enhance the productivity of an organization. This can be seen in the implementation of strategies to reduce costs, better quality and more flexibility that are initially introduced in the manufacturing sector. The shift in thinking, he added, to transform the implementation to the service sector from manufacturing, started in the 1970s. Krishnan and Parveen [14] compared the application of Lean in the manufacturing and service sectors. Their study consisted only the health service. Lean approach in TQM, JIT and HRM are practiced more frequently in both the sectors and found more significant the application of lean in HRM of service sector as compared to manufacturing sector. Another study Taj [15] examined the refitting of the Lean principle in manufacturing. Similarly Robb, Xie, and Arthanari [16] analyzed the relationship between operations practices and financial performance and showed that operations practices do not have significant impact on financial performance of organizations. Hines, Holweg, and Rich [17] showed the Lean application focusing on "shop floor" waste elimination and reducting the cost to another application which tries to enhance a particular value in the services aspect i.e. satisfy the customer or put interest on the prospective customer and also analyzed the relationship between value, cost and waste in the services sector. Bhuiyan and Baghel [18] explained waste as something that the customer is not willing to pay. Waste or situation is often seen in services sector as this sector involves many customers. Waste in service can also be defined as mistakes /interruptions / delays in providing the services to customers by an organization [19]. $\mathrm{Li}$ [20] investigated the intermediate infrastructural manufacturing decisions, which includes workforce management, production control and new technology applications' influence on an organization's market performance. Li [21] developed Relationship between performance and competitiveness in manufacturing organizations. Their measurement of performance is based on sales, profit after tax, and return on investment. The measurement of competitiveness is based on marketing, product design and its development, product manufacturing and human resources. Cua,et.al. [22], found concurrent appliance of TQM as total productive management. Sakakabira et al [23] developed relationship between JIT and quality performance. Pedersen and Huniche [24, 25 ] found that by Increasing the customer value decreases the wastes. Shah and Ward [26, 27] defined waste defined as difference between suppliers, customers and organizations. Similarly Taj and Morosan [28] observed lean as production without waste.

\section{Results and Discussion}

Concepts of lean must be implemented in higher education sector in all universities /institutions to improve the quality of education by minimizing the wastes by carefully designing the course planning and delivery process of teaching, learning academic \& administration. India will certainly improve its ranking in the world by providing quality education in the higher education sector by using lean principles. Using lean principles in the manufacturing and service sectors, the wastes were minimized. Similarly in the higher education lean principles will certainly improve best quality in higher education achieving desired goal.

\section{Conclusions}

Following conclusions were made

- Several wastes exist in the course and in its delivery process.

- By proper planning in the higher education sector, the wastes will be minimized.

- The effect of Lean applications on satisfaction of students is an important indicator.

- The implementation of lean application in all universities/implementation in India gives will certainly improvement.

\section{References}

[1] Nightingale, D. (2000) E-lean Presentation [online]. available from <http://lean.mit.edu/> [22 Jun 2013]

[2] Nightingale, D. (1999) Lean Enterprise Model.

[3] Logothetis, N. (1995) 'Towards a Quality Management of Education'. Total Quality Management 6 (5/6), 479-486

[4] Spanbauer, S.J. (1995) 'Reactivating Higher Education with Total Quality Management: Using Quality and Productivity Concepts, Techniques and Tools to Improve Higher Education'. Total Quality Management 6 (5/6), 519-537

[5] Dahlgaard, J.J., Kristensen, K., and Kanji, G. (eds.). (1995) ‘A Special Issue on 'Total Quality in Education' '. Total Quality Management 6 (5\&6), 443619

[6] Green, D.A. (ed.) (2013) 'Academic Development in the Evolution of Higher Education'. International Journal for Academic Development 18 (3), 205-207

[7] Domonio, M.S. (2011) 'A New Lean Paradigm in Higher Education: A Case Study'. Quality Assurance in Education 19 (3), 248 - 262

[8] Collins, K., and Muthusamy, S. (2007) 'Applying the Toyota Production System to a Healthcare Organization: A Case Study on a Rural Community Healthcare Provider'. The Quality Management Journal 14 (4), 41-52 Collins and Muthusamy [2007]

[9] Womack, J., and Jones, D. (1996) Lean Thinking. London: Touchstone

[10] Womack, J., and Jones, D. (2003) Lean Thinking: Revised and Updated. New York. 
[11] Martin, W. (2007) 'Quality Models: Selecting the Best Model to Deliver Results'. The Physician Executive 2 (5), 24-29

[12] Levitt, T. (1972) 'Production Line Approach to Service'. Harvard Business Review 50 (5), 20-1

[13] Skinner, W. (1969) 'Manufacturing-Missing Link in Corporate Strategy'. Harvard Business Review 47 (3), 136-145 Skinner[1969]

[14] Krishnan, V., and Parveen, C.M. (2013) 'Comparative Study of Lean Manufacturing Tools Used in Manufacturing Firms and Service Sector'. Proceedings of the World Congress on Engineering 2013

[15] Taj, S. (2008) 'Lean Manufacturing Performance in China: Assessment of 65 Manufacturing Plants'. Journal of Manufacturing Technology Management 19 (2), 217-234 281 Taj (2008)

[16] Robb, D.J., Xie, B., and Arthanari, T. (2008) 'Supply Chain and Operations Practice and Performance in Chinese Furniture Manufacturing'. International Journal of Production Economics 112 (2), 683-699

[17] Hines, P., Holweg, M., and Rich, N. (2004) 'Learning to Evolve: A Review of Contemporary Lean Thinking'. International Journal of Operations \& Production Management 24 (10), $994-1011$

[18] Bhuiyan, N., and Baghel, A. (2005) 'An Overview of Continuous Improvement: From the Past to the Present'. Management Decision 43 (5), 761-71

[19] Brandao De Souza, L. (2009) 'Trends and Approaches in Lean Healthcare'. Leadership in Health Service 22 (2), 121-39

[20] Li, L. (2005) 'Assessing Intermediate Infrastructural Manufacturing Decision that Affect a Firm's Market Performance'. International Journal of Production Research 43 (12), 2537-2551
[21] Li, L. (2000) 'An Analysis of Sources of Competitiveness and Performance of Chinese Manufacturers'. International Journal of Operations \& Production Management 20 (3), 299-315 273

[22] Cua, K.O., Mckone, K.E., and Schroeder, R.G. (2001) 'Relationships between Implementation of TQM, JIT, and TPM and Manufacturing Performance'. Journal of Operations Management 19 (2), 675-694

[23] Sakakibara, S., Flynn, B.B., Schroeder, R.G., and Morris, W.T. (1997) 'The Impact of Just-in-Time Manufacturing and its Infrastructure on Manufacturing Performance'. Management Science 43 (9), 1246-1257

[24] Pedersen, E.R.G., and Huniche, M. (2011a) 'Determinants of Lean Success and Failure in the Danish Public Sector: A Negotiated Order Perspective'. International Journal of Public Sector Management 24 (5), 403 - 420

[25] Pedersen, E.R.G., and Huniche, M. (2011b) 'Negotiating Lean: The Fluidity and Solidity of New Management Technologies in the Danish Public Sector'. International Journal of Productivity and Performance Management $60(6), 550-566$

[26] Shah, R. and Ward, P.T. (2007) 'Defining and Developing Measures of Lean Production'. Journal of Operations Management 25, 785-805

[27] Shah, R., and Ward, P. (2003) 'Lean Manufacturing Context, Practice Bundles, and Performance'. Journal of Operations Management 21 (2), 129149279

[28] Taj, S., and Morosan, C. (2011) 'The Impact of Lean Operations on the Chinese Manufacturing Performance'. Journal of Manufacturing Technology Management 22 (2), 223-240.

Cite this article as: Kamini Mishra, Lean applications in improving quality by minimizing wastes in higher education sector in Indian context- A review, International Journal of Research in Engineering and Innovation Vol-3, Issue-6 (2019), 527-529.

https://doi.org/10.36037/IJREI.2019.3615 